\title{
Urban environments provide opportunities for early detections of Phytophthora invasions
}

Joseph M. Hulbert ${ }^{1,4}$, Michelle C. Agne ${ }^{2}$, Treena I. Burgess ${ }^{1,3}$, Francois Roets ${ }^{4}$, Michael

J. Wingfield ${ }^{1}$

${ }^{l}$ Forestry and Agricultural Biotechnology Institute, Department of Plant and Soil Science, University of Pretoria, Pretoria, 0002, South Africa.

${ }^{2}$ School of Environmental and Forest Sciences, University of Washington, 98195, USA.

${ }^{3}$ Centre for Phytophthora Science and Management, School of Veterinary and Life Sciences, Murdoch University, Murdoch, 6150 Western Australia.

${ }^{4}$ Department of Conservation Ecology and Entomology, Stellenbosch University, Stellenbosch, 7600, South Africa.

Corresponding author: Joseph M. Hulbert, joey.hulbert@fabi.up.ac.za, +27738713066, OCRID: 0000-0002-7921-3572

\section{Abstract}

Globalization has increased the frequency of inadvertent introductions of plant pathogens. Many catastrophic invasions of both natural and agricultural systems have been initiated through anthropogenic dissemination pathways. Phytophthora species are a group of invasive plant pathogens causing many of the most important plant disease epidemics. A review of Phytophthora species descriptions published following the publication of the first DNA-based Phytophthora phylogeny was conducted to highlight patterns of recent introductions and to provide insights for early pathogen detection initiatives. Seventy-two publications from 2001-2016 describing 98 Phytophthora species 
were evaluated. Of the 91 species with geographic location isolation data, $22 \%$ of species were described from type specimens isolated from urban environments, 33\% from agricultural environments and $45 \%$ from natural environments. Within the urban environment, ornamental plant trading nurseries were the most important sources. Specifically, for Phytophthora ramorum, a species causing multiple epidemics globally, the largest proportion of first report publications were from urban environments, including nurseries. Nearly a quarter of the species descriptions were based on isolates from the urban environment, including ornamental nurseries, and the majority of the first reports for $P$. ramorum were also from this environment. We therefore suggest that detection programs for invasive plant pathogens within the urban environment would be valuable. In this regard, specialized monitoring and citizen science projects that target urban areas where live plant-trading industries are concentrated would be particularly effective to both promote early detection and to facilitate a rapid response to new species invasions.

\section{Keywords}

Phytophthora, urban environment, biological invasions, citizen science, ornamental plants, biosecurity 


\section{Introduction}

Natural environments are becoming increasingly homogenized due to globalization and the anthropogenic movement of species. The spread of invasive plantpathogenic organisms such as Phytophthora species (Oomycetes) is a global concern for nature conservation because of epidemics such as sudden oak death (USA), ramorum blight (UK), Phytophthora dieback (AUS) and protea root rot (RSA). Phytophthora cinnamomi, for example, has been described as one of the most destructive plant pathogens in the world (Brasier 1996; Burgess et al. 2016), metaphorically referred to as a 'biological bulldozer' in Australia (Hardy et al. 2007; Scott et al. 2013). It is thus included in the International Union for the Conservation of Nature (ICUN) list "100 of the World's Worst Invasive Alien Species" (Lowe et al. 2000).

Improving methods to control invasive species is important for several reasons. Invasive species threaten the biodiversity of natural systems (Vitousek et al. 1996; Crowl et al. 2008; Gaertner et al. 2009), and consequently the functions of and services provided by the ecosystems, ultimately affecting human health (Pejchar and Mooney 2009; Pyšek and Richardson 2010; van Wilgen et al. 2012; Donovan et al. 2013). Biodiversity is suggested to be the world's greatest resource (Wilson 1989) and is essential to maintain ecosystem functions and services (Mace et al. 2012). Controlling invasive species is important because they have been shown to drive biodiversity loss (Wilson 1989; Vitousek et al. 1996) and degrade ecosystems (Pyšek and Richardson 2010; Hooper et al. 2012).

Microscopic invasive organisms such as plant pathogens provide serious challenges when attempting to manage invasions. This is partly because there are large numbers of undiscovered and undescribed species that cannot be controlled with current 
regulatory approaches and biosecurity practices based on taxonomy (Brasier 2008;

McTaggart et al. 2016; Crous et al. 2016). Many biosecurity programs use biogeographic information to focus their monitoring efforts, but even for known invasive species, the distribution data are often incomplete (Scott et al. 2013). For example, the origins of many Phytophthora species remain unknown. Furthermore, there are many different pathways of movement (e.g. nursery plant trade, wood packaging material, residual soil on equipment), each with their own management complications.

Countries actively managing invasive species have limited options for investing time and energy, and the available options are highly dependent on the invasion stage of the organism. These investments can be made in several management strategies, including: prevention, monitoring and detection, eradication, containment (treatment or management to slow the spread of species), mitigation, or restoration. Of these strategies, prevention has been widely described as the investment that is most economical and most likely to be successful (Leung et al. 2002; Chornesky et al. 2005; Hulme 2006, 2009; Hansen 2015; Wingfield et al. 2015; Faulkner et al. 2015). However, for already introduced organisms, the first steps in addressing the problem are detection followed by monitoring (Pyšek and Richardson 2010).

Early detection and monitoring of invasive species requires many trained observers. Citizen science initiatives provide new quantitative approaches to investigate the distribution and abundance of organisms across space and time with minimal costs (Bonney et al. 2009; Dickinson et al. 2010; Gallo and Waitt 2011). Such initiatives have been used for the early detection and monitoring of invasive species (Crall et al. 2015) 
and are suitable for surveying Phytophthora species (Meentemeyer et al. 2015), possibly benefiting resource-limited agencies and economies.

To determine priorities for invasive plant pathogen early detection and monitoring efforts, we reviewed recent published studies that describe Phytophthora species in order to identify the environment and the economic status of the country in which each species was isolated. We further reviewed first reports of P. ramorum to identify the types of environments in which this pathogen has been found throughout its distribution. Finally, we summarized four citizen science projects that facilitate Phytophthora research as examples of programs that could be implemented to increase our understanding of the effects of Phytophthora species and our ability to manage their invasions.

Comprehensively, this review presents a partial summary of recent Phytophthora species surveys and provides justification to survey urban environments while proposing citizen science as an ideal tool.

\section{Review of Phytophthora species described after 2001}

This review is comprised of all studies between 2001 and 2016 that include descriptions of Phytophthora species. We chose to limit the review to the period following the publication of the first ITS-based phylogeny for Phytophthora by Cooke et al. (2000) in order to limit inaccuracies in descriptions based on morphology and other less quantitative characters. Numerous species have been described during this period because of increased numbers of Phytophthora surveys and several species have been reclassified due to the improved tools available for identification of species (Scott et al. 2013).

Data were based on type specimens that were used to describe the Phytophthora species primarily because this ensured accuracy of species identity. Furthermore, type 
specimens are typically the first isolates collected for a given species. Where "type" information was not provided in a publication, locality and environmental data were compiled from descriptions of disease occurrence and habitat. In a few cases, the authors acknowledged that the type specimen was not the first isolate collected (Hansen et al. 2009) or that an isolate had been collected previously at a different location and had been included to complete the description (Bertier et al. 2013). In the case where holotype specimens had not yet been designated (e.g. Phytophthora taxon parsley, Phytophthora taxon castitis), geographic information was based on the first isolate collected (Bertier et al. 2013). In some cases, additional information was compiled by using documented NCBI GenBank (https://www.ncbi.nlm.nih.gov/) or CBS accession numbers (http://www.westerdijkinstitute.nl/Collections/).

We treated Phytophthora species having type specimens recovered from planted forests of exotic tree species as isolations from agricultural environments because they are intensively managed. Type specimens recovered from ornamental plant nurseries and garden centers were considered to be from urban environments. Conversely, we classified isolations from plant production nurseries as isolations from agricultural environments because they were producing stock for restoration of native species or reforestation of exotic species. Although some ornamental nurseries may occur in rural areas, we chose to classify these as urban environments for several reasons. We assume that the majority of plant trading nurseries and garden centers are within or close to urban environments, and that ornamental plants are most likely to be purchased for planting in urban and residential areas, rather than natural or agricultural environments. Furthermore, the majority of species description manuscripts do not provide enough detail to distinguish 
the locality of the nurseries from which the isolates were recovered. Further review of the species descriptions from urban environments was conducted to identify whether species had subsequently been isolated from natural environments. When species descriptions did not state whether a species had also been detected in natural environments, a literature search was conducted to further verify whether additional detections occurred later.

A comprehensive review of the literature yielded 73 publications describing 98 Phytophthora species. Fifteen species in these publications were taxonomic revisions or reclassifications of previously informally described species, while five species had only “informal" descriptions (e.g. Phytophthora taxon parsley). Geographic location data associated with the isolation of the type specimen were provided in the descriptions for 91 species between 2001-2016. Of the seven descriptions that did not provide clear geographic location data for the isolation of the type specimen, two included isolates from urban environments as additional specimens for the species description.

\section{Phytophthora species in the environment}

In our review of the literature, type specimens for 20 species were recovered from urban environments. These recoveries represented $22 \%$ of the species with geographic location data associated with the isolation of the type specimen described between 2001 and 2016 (Table 1, Figure 1). Of these species, one was recovered from a botanical garden (Henricot et al. 2014), one was recovered from ornamental trees along an urban street (Brasier et al. 1993; Hansen et al. 2015), and four additional species were recovered from public spaces (Belbahri et al. 2006; Grünwald et al. 2012b; Scanu et al. 2014).

In a few cases, the location of the isolation of the type specimen was ambiguous. For example, location data for the type specimen of $P$. parvispora was described as an 
ornamental planting, which we considered as a public space because of the park-like setting in the host images (Scanu et al. 2014). Other locations included in our designation as a public space were described as an alleé (Grünwald et al. 2012b) and an alder stand within a town (Belbahri et al. 2006).

The remaining 14 species with type specimens from urban environments were recovered from ornamental plant nurseries or garden centers (Figure 2), representing the most important source of type specimens from the urban environment. The majority of species from urban environments were described with type specimens from ornamental nurseries, including their irrigation reservoirs. In addition, 10 of these species were also recovered in ornamental nurseries elsewhere (Table 1). This finding is not surprising considering that the trade of living plants is widely recognized as the primary pathway for many plant pathogen invasions (Brasier 2008; Liebhold et al. 2012), especially for Phytophthora species (Jung et al. 2016b).

Thirty species of Phytophthora were described with type specimens from agricultural environments in 15 countries (Figure 1), representing 33\% of the species included in this review. Five Phytophthora species (P. alticola, P. captiosa, P. fallax, P. frigida, and $P$. pinifolia) were isolated from plantations of non-native trees (Dick et al. 2006; Maseko et al. 2007; Durán et al. 2008). Some of these species may have been introduced into the agricultural systems in which they were recovered, but others may represent native species that were first detected on exotic hosts (Wingfield et al. 2015). As a result of both pathways, Phytophthora species continue to emerge as important pathogens in agricultural systems and preventing their movement and establishment is necessary in the mitigations of their deleterious effects. 
The remaining 42 Phytophthora species, representing $45 \%$ of the species in this review that had type specimen geographic location data, were described based on isolates from natural environments in at least 13 countries (Figure 1). While this finding reflects the substantial diversity of Phytophthora in natural environments, many of these species could have been isolated during surveys of other invasive Phytophthora species (Burgess et al. 2009), or in exploratory surveys led by international researchers searching for the origin of newly described species (e.g. Jung et al. 2016a; Jung et al. 2017).

In theory, all Phytophthora species originate from a natural environment, but only become invasive "open-ended experiments in evolution" once transported and exposed to new environments and hosts (Hansen 2008; Brasier 2008; Hansen 2015). Although generally benign because of their coevolution with their hosts in native habitats, surveys of natural environments and the subsequent description of species before they "escape," is critical for establishing baseline datasets for each country or region and for global biosecurity initiatives aimed at prevention (Burgess et al. 2017). Increased exploration of habitats that have not been studied is needed to reveal the full diversity and current distributions of Phytophthora species (Hansen et al. 2012).

Eight of the 20 species described based on isolates from urban environments have also been reported in natural environments (Table 1). To find this large proportion is concerning because of the strong link between Phytophthora species dissemination and the trade of living plants, giving these species opportunities to move through urban environments or be dispersed around the world. Jung et al. (2016b) reported that 49 Phytophthora species are widespread throughout the nursery trade in Europe. If our results are representative of this situation, it would mean that as many as 20 of these 
European nursery-associated species will also be found within natural environments, possibly as a result of invasions from urban environments, including ornamental nurseries. Although we did not assess the direction of movement between nurseries and the natural environment for the eight species in our review, this proportion illustrates the potential risk of Phytophthora invasions into natural environments for countries engaged in the trade of ornamental nursery stock.

0 The abundance of Phytophthora species within ornamental nursery settings is a major concern as plant trading nurseries are the most important source of Phytophthora invasions because they are linked to global shipping networks (Brasier 2008; Jung et al. 2016b). Phytophthora species have been recovered from soil of potted plants (Davison et al. 2006), irrigation reservoirs (Ghimire et al. 2011; Yang et al. 2016), and hundreds of different hosts with novel plant-microbe interactions (Moralejo et al. 2009; Jung et al. 2016b). Nurseries also provide opportunities for hybridization between species (Brasier 2001; Brasier et al. 2004), where progeny can have novel host specificities and effects (Érsek et al. 1995; Brasier et al. 1999). Novel plant-microbe interactions are often unpredictable and can serve as a new means for escape into the natural environment. For example, Phytophthora species on weeds or other new hosts can be cryptic and infections do not always induce symptoms on the host (Denman et al. 2009; Migliorini et al. 2015). The asymptomatic plants may then be transported allowing for inadvertent pathogen movement, potentially on a global scale. Regardless of the setting in the urban environment, targeting these invasions before they escape into natural environments is critical for the protection of biodiversity and natural resources. 


\section{Phytophthora species in economies around the world}

Utilizing the classification of the International Monetary Fund World Economic

Outlook (WEO 2016), it was possible to characterize the economic environments where Phytophthora species have been described. Based on type specimens, 44 species were collected in countries with major advanced economies, 34 species from advanced economies and 13 species were from countries with emerging markets and developing economies (Figure 3). Only one species (P. polonica) had a type specimen recovered from an urban environment in a country with an emerging market and developing economy (Belbahri et al. 2006).

The positive correlation between the number species descriptions and IMF economy classifications could suggest that countries with emerging markets and developing economies are under-surveyed. An alternative explanation may be that smaller international markets imply a lower risk of invasion due to lower levels of trade or movement of people. Nonetheless, the Phytophthora species found in countries with developing economies are of global concern because of phenomena such as the "bridgehead effect" (Lombaert et al. 2010; Scott et al. 2013; Wingfield et al. 2015) that strongly influences subsequent invasions into new environments. The concept of the "bridgehead effect" implies that once an area becomes a sink of an invasive species, it can be a source to other areas (Lombaert et al. 2010).

In terms of global occurrence, Phytophthora species were described in only 23 countries between 2001 and 2016. This information suggests that Phytophthora species remain to be described from much of the rest of the world. For example, only three species have been described from Africa ( $P$. capensis, $P$. frigida, and $P$. alticola). This is of great concern because according to UN trade statistics (data not shown), Africa's 
exports of living plants are increasing; for example, Jung et al. (2016b) suggested that Africa supplied 3.6 billion plants to the Netherlands, accounting for $83.7 \%$ of the imports from overseas in 2010 alone.

\section{Phytophthora ramorum: an example of a globally invasive plant pathogen}

A detailed examination was conducted for $P$. ramorum by reviewing first report

publications. This species was chosen as a case study because of its international importance as a pathogen, but also because it represents an invasive Phytophthora species that was released into an urban environment and subsequently spread to natural environments. The origin of P. ramorum remains unknown, but it was described based on isolates from ornamental plant nurseries in Germany and the Netherlands in 2001 and simultaneously identified as the cause of the ongoing sudden oak death epidemic in the urban environment of California (Garbelotto et al. 2001; Werres et al. 2001; Rizzo et al. 2002; Rizzo and Garbelotto 2003).

The importance of urban and residential monitoring programs such as university extension programs is validated by the establishment story of $P$. ramorum. The initial report of dying tanoaks arose when homeowners asked University of California (UC) Cooperative Extension to investigate the cause of mortality for many trees bordering a creek in Marin County (Garbelotto et al. 2001). This mortality was subsequently found to be associated with the planting of ornamental rhododendrons in the understory (Rizzo et al. 2002). Then, within two years, the pathogen had spread along the creek and up the slopes to the crest of the hill and the first coast live oaks began to die in gardens of Marin County (Garbelotto et al. 2001). The existence of the UC Cooperative Extension program enabled the first report from a citizen and the following detection of the pathogen. 
Since its first discovery and description (Werres et al. 2001), 72 first reports for $P$. ramorum have been published from various parts of the world. These reports were made for close to 60 host species in 14 countries on three continents. Additional reports were published when different lineages of $P$. ramorum were found in additional areas (e.g. Garbelotto et al. 2013), but these reports have not been included in the present study. Forty-eight publications representing 58 different host species included unambiguous geographic data that could be used in this review (Table 2).

First reports have been published for $P$. ramorum discoveries in urban, agricultural, and natural environments. Forty-seven of these first reports were for hosts in urban environments, 18 in natural environments, and 5 from agricultural environments. One additional report was from multiple environments in the UK (Table 2, Denman et al. 2005). While this distribution represents the prioritization for monitoring efforts in urban settings, often associated with statutory monitoring of plant nurseries (O'Hanlon et al. 2016), it does not necessarily suggest that $P$. ramorum could not be detected in natural environments. However, only 3 of the 14 countries that contributed first reports have reported $P$. ramorum in non-urban environments.

The majority of first reports of $P$. ramorum were from the two countries with active disease epidemics related to the pathogen: the United States and the United Kingdom. Phytophthora ramorum was discovered in a greater diversity of environments for these countries than all other countries combined (Table 2, Figure 4). In all other countries, the majority of reported first detections occurred in nurseries and subsequent first reports have not been published for discoveries in natural or agricultural environments. 
While our results are limited to publications of 'first reports', many other reports of novel $P$. ramorum host interactions exist but were not included in this review (e.g. Hansen et al. 2005). Therefore, the summary presented here is likely an underrepresentation of the current distribution and host range of $P$. ramorum, which is also limited because it is a quarantined species, listed in regulatory or legislative frameworks of more than 60 countries (Sansford et al. 2009). Nonetheless, we suggest that the frequency of recovering and reporting it in urban environments fairly represents a species that emerged through the trade of nursery stock, which is the most important source of Phytophthora species dissemination.

\section{Recommendations}

The findings of this review are consistent with previous studies regarding the association of Phytophthora species with plant nurseries (Moralejo et al. 2009; Jung et al. 2016b; O'Hanlon et al. 2016) and support the consensus that Phytophthora species are frequently disseminated via the plant trade. Therefore, we suggest that monitoring urban environments is especially important for countries that are engaged in the international trade of living plants.

We recommend monitoring ornamental nurseries and the surrounding urban environments because we predict a substantial proportion of the currently undiscovered Phytophthora species will be found in these areas, given the findings of this review. As many as 500 Phytophthora species are estimated to exist (Brasier 2008). Assuming that the results of this review represent future trends, we estimate that approximately 110 species will be described based on type specimens found in urban environments.

Monitoring nurseries and the surrounding urban environments is important because of the severe risk posed by species such as $P$. ramorum, which provides an 
excellent example of a previously undiscovered Phytophthora species first found in the urban environment with evidence for emergence through the trade of nursery stock (Rizzo et al. 2002; Grünwald et al. 2012a). Focusing monitoring efforts in these areas will promote the early detection and rapid response required to prevent inadvertent movement of Phytophthora species into natural and agricultural environments.

Furthermore, this focus would enable countries with limited resources for monitoring to detect and control invasive Phytophthora species.

It is important to monitor urban environments because they include most ports-ofentry, which are largely recognized as critical areas for early detection of plant pests and pathogens (McCullough et al. 2006; Aukema et al. 2010). The importance of monitoring the urban environment is also supported by a recent study in British Columbia that found greater diversity of Phytophthora species in urban environments than natural environments (Dale et al. 2017). The relationship between the increased diversity in urban environments and the proximity to ports-of-entry may be attributed to the trade of nursery stock (Liebhold et al. 2012) and supports the suggested need for increased monitoring in urban areas.

To the best of our knowledge, this review is the first attempt to establish a comprehensive list of Phytophthora species that have been discovered in urban environments. However, because we have limited this study to specimens used in species descriptions, our list of species is most likely an underrepresentation and does not reflect the actual number of Phytophthora species in urban environments. For example, Barber et al. (2013) recorded five species of Phytophthora killing trees in urban environments in Australia. Four of these species were described after 2001, but none of those were 
described using isolates from urban environments. Unfortunately, there are few studies similar to those of Barber et al. (2013) on which to base a more thorough review of Phytophthora in urban environments.

6 Although one-third of the species included in this review were isolated from agricultural environments, monitoring is usually intrinsic to agricultural production because local growers often report new invasions. For example, most species described from isolates in this environment were described following the identification of problems. However, this scenario also depends on the level of education, access to scientific communities, and the knowledge required to recognize the problem as having a biological origin. This may not occur in many countries with developing economies. In these cases, raising awareness about the threats and consequences of invasive plant pathogens would promote the reporting of invasions and subsequent species descriptions.

Specifically surveying ornamental nurseries could prevent local invasions of undetected pathogens moving from nurseries to neighboring natural or urban environments and this could also prevent the pathogen from being shipped elsewhere. While detection of an invasive pathogen in a nursery could represent a disruption of the plant-trade pathway (i.e. the host and pathogenic material are destroyed before they are shipped or before they can establish outside), it may also represent a late detection of a completed introduction to the outside environment. The latter possibility is welldemonstrated by the case in Norway, where $P$. ramorum was first detected in a nursery, and was later found on public land that had plantings from the nursery (Herrero et al. 2006). Therefore, monitoring ornamental nurseries should be the priority in all countries 
because they pose the most immediate risk for dissemination, but broader urban surveys are also needed.

Although detection and monitoring programs should be prioritized in nurseries, we caution that countries should not overlook the importance of pathogen monitoring outside of nurseries. Particularly in areas where nursery detections of aggressive plant pathogens have occurred, monitoring of the nearby urban environment could provide the opportunity to eradicate an invasive plant pathogen before it escapes into a natural environment. Many Phytophthora species have been isolated from irrigation reservoirs running from nurseries (Ghimire et al. 2011), and movement from aquatic environments into terrestrial ecosystems has also been observed (Werres et al. 2007; Hulvey et al. 2010). Monitoring these areas in combination with nurseries would provide the best chance to detect a newly introduced Phytophthora species before it escapes into other environments.

Monitoring activities in urban environments such as residential neighborhoods or public gardens or arboreta, and natural areas that receive considerable human activity, such as national parks, could also provide opportunities for the early detection of Phytophthora species invasions. Several Phytophthora descriptions were based on isolates from public spaces and botanical gardens. The importance of monitoring these areas is recognized and acted upon by the International Plant Sentinel Network (IPSN), a platform to connect gardens with monitoring efforts and exchange information internationally (Barham et al. 2015). These settings within the urban environment are also well suited for citizen science projects, especially in situations where monetary resources are focused on monitoring nurseries or where university extension programs do not exist. 
Training professionals to monitor ornamental nurseries and to conduct port inspections is important. But training non-scientists through programs such as the IPSN and citizen science projects would maximize detections in broader urban environments that are missed at the first stages (port inspections or in nurseries) of an invasion. In this regard, Brown et al. (2017) recently concluded that incorporating public contributions in plant pest monitoring efforts can maximize the use of resources for regulatory surveys. Therefore, where possible, monitoring ports and nurseries, embracing the IPSN, and establishing citizen science projects would provide the best possible combination of actions for the early detection of Phytophthora species within the urban environment.

\section{Citizen Science projects that facilitate research about Phytophthora species \\ Citizen science initiatives can mitigate the effects of invasive species through} supporting monitoring in resource-scare countries or countries that underfund such efforts. The methods used in citizen science initiatives broaden sampling distribution and can offset the prohibitive costs of data collection (Bonney et al. 2009; Meentemeyer et al. 2015; Hulbert 2016). Such projects have exceptional merit for monitoring invasive species because of the incorporation of 'many eyes' and greater access to private lands. In this regard, four citizen science projects have been established to survey, monitor and treat Phytophthora species. These include: the Sudden Oak Death (SOD) Blitz Program and the Phytophthora Stream Monitoring Program in the USA, Kauri Rescue in New Zealand, and Cape Citizen Science in South Africa.

The SOD Blitz program (https://nature.berkeley.edu/garbelottowp/) facilitates the regional monitoring of the Sudden Oak Death pathogen Phytophthora ramorum in California. Public contributions to the SOD Blitz program have improved predictive modeling capacity and informed managers of hot-spots for disease emergence in both 
urban and natural environments (Meentemeyer et al. 2015). The project has also demonstrated that members of the public are equally capable of recognizing the disease than professionals. This result highlights the value of engaging the public in Phytophthora research and promotes non-scientist training programs as a valuable resource for monitoring invasive species in urban and rural environments.

The Phytophthora Stream Monitoring Program (https://ppo.puyallup.wsu.edu/sod/monitoring/streams/) is a project in western Washington State that gathers baseline data on Phytophthora species in streams in urban and wildland areas. The project was initiated to facilitate early detection of Phytophthora ramorum, but has since broadened its focus to survey multiple genera (Elliott et al. 2017). Through engagement of volunteer organizations, landowners, students, and the general public, the project has increased awareness of waterborne plant pathogens and the importance of sanitation.

Kauri Rescue (http://www.kaurirescue.org.nz) is an initiative to engage a broad community in the control of Phytophthora agathidicida, which is killing culturally and environmentally important kauri (Agathis australis) trees (Weir et al. 2015). Because kauri dieback is an issue in the urban interface, the project invites citizens to test treatment methods (e.g. phosphite application) and thus to determine the best approach for control. Although this project is not necessarily a monitoring program, it demonstrates the merit of involving the public to test hypotheses that seek to reduce the impacts of Phytophthora species while also raising awareness of the problem.

Cape Citizen Science (http://citsci.co.za) facilitates research regarding the diversity and distributions of Phytophthora in southwestern South Africa. It has also 
demonstrated that citizens are invaluable for plant disease research in both urban and natural environments. The program uses a model in which participants can contribute by sharing observations of plant disease or by submitting samples for analysis. The project has received many isolates of Phytophthora from citizens because it offers training to recognize plant diseases and methods to isolate causal organisms. Specifically in the urban environments, the project and has received samples from both plant trading industries and home gardens. In contrast to the other initiatives, Cape Citizen Science is pioneering methods to engage the public and survey Phytophthora diversity in a country with a developing economy.

\section{Conclusions}

5 Because of the frequency and diversity of Phytophthora species found within the urban environment, and the potential for these pathogens to move to new environments, we recommend prioritizing monitoring efforts in the urban environment. This focus is especially recommended in countries with limited resources that engage in the trade of plants for planting. The summary provided by this review, coupled with the consensus regarding the risks posed by the trade in living plants, suggests that monitoring nurseries and the greater urban environment provides opportunities to detect invasive Phytophthora species before they escape into other environments. While it remains critical to train professionals and specialists to monitor plant-trading nurseries, we recommend citizen science as an approach to offer training for non-scientists, similarly to the IPSN, to monitor and discover Phytophthora species in urban and natural environments.

\section{Acknowledgments}

We thank Paul Reeser for providing copies of many of the species descriptions initially used in this study. We also thank the project leaders of the citizen science initiatives, 
Prof. Matteo Garbelotto, Dr. Marianne Elliot, and Dr. Ian Horner, for their untiring

efforts to demonstrate the value of community engagement in Phytophthora research.

This study benefitted from financial support of the Department of Science and

Technology (DST)-National Research Foundation (NRF) Centre of Excellence in Tree

Health Biotechnology (CTHB; http://www.fabinet.up.ac.za/research-groups/dst-nrf-

centre-of-excellence-in-tree-health-biotechnology) and also from support contributed to

the crowd-funding campaign "Discovering Plant Destroyers in South Africa with Citizen

Science" (doi: 10.18258/2066).

\section{References}

Aukema JE, McCullough DG, Holle BV, et al (2010) Historical Accumulation of Nonindigenous Forest Pests in the Continental United States. BioScience 60:886897. doi: $10.1525 /$ bio.2010.60.11.5

Barber PA, Paap T, Burgess TI, et al (2013) A diverse range of Phytophthora species are associated with dying urban trees. Urban For Urban Green 12:569-575. doi: 10.1016/j.ufug.2013.07.009

Barham E, Sharrock S, Lane C, Baker R (2015) An International Plant Sentinel Network. Sibbaldia J Bot Gard Hortic 0:83-98.

Belbahri L, Moralejo E, Calmin G, et al (2006) Phytophthora polonica, a new species isolated from declining Alnus glutinosa stands in Poland. FEMS Microbiol Lett 261:165-174. doi: 10.1111/j.1574-6968.2006.00349.x

Bertier L, Brouwer H, Decock AWAM, et al (2013) The expansion of Phytophthora clade 8 b: three new species associated with winter grown vegetable crops. Persoonia Mol Phylogeny Evol Fungi 31:63-76. doi: 10.3767/003158513X668554

Bonney R, Cooper CB, Dickinson J, et al (2009) Citizen Science: A Developing Tool for Expanding Science Knowledge and Scientific Literacy. BioScience 59:977-984. doi: $10.1525 /$ bio.2009.59.11.9

Brasier CM (1996) Phytophthora cinnamomi and oak decline in southern Europe. Environmental constraints including climate change. Ann Sci For 53:347-358. doi: $10.1051 /$ forest: 19960217 
Brasier CM (2008) The biosecurity threat to the UK and global environment from international trade in plants. Plant Pathol 57:792-808. doi: 10.1111/j.13653059.2008.01886.x

Brasier CM (2001) Rapid Evolution of Introduced Plant Pathogens via Interspecific Hybridization. BioScience 51:123-133. doi: 10.1641/00063568(2001)051[0123:REOIPP]2.0.CO;2

Brasier CM, Cooke DEL, Duncan JM (1999) Origin of a new Phytophthora pathogen through interspecific hybridization. Proc Natl Acad Sci 96:5878-5883. doi: 10.1073/pnas.96.10.5878

Brasier CM, Hamm PB, Hansen EM (1993) Cultural characters, protein patterns and unusual mating behaviour of Phytophthora gonapodyides isolates from Britain and North America. Mycol Res 97:1287-1298. doi: 10.1016/S09537562(09)80160-3

Brasier CM, Kirk SA, Delcan J, et al (2004) Phytophthora alni sp. nov. and its variants: designation of emerging heteroploid hybrid pathogens spreading on Alnus trees. Mycol Res 108:1172-1184. doi: 10.1017/S0953756204001005

Brown N, van den Bosch F, Parnell S, Denman S (2017) Integrating regulatory surveys and citizen science to map outbreaks of forest diseases: acute oak decline in England and Wales. Proc R Soc B Biol Sci 284:20170547. doi: $10.1098 / \mathrm{rspb} .2017 .0547$

Burgess TI, Scott JK, Mcdougall KL, et al (2016) Current and projected global distribution of Phytophthora cinnamomi, one of the world's worst plant pathogens. Glob Change Biol n/a-n/a. doi: 10.1111/gcb.13492

Burgess TI, Webster JL, Ciampini JA, et al (2009) Re-evaluation of Phytophthora Species Isolated During 30 Years of Vegetation Health Surveys in Western Australia Using Molecular Techniques. Plant Dis 93:215-223. doi: 10.1094/PDIS-93-3-0215

Burgess TI, White D, McDougall KM, et al (2017) Distribution and diversity of Phytophthora across Australia. Pac Conserv Biol. doi: 10.1071/PC16032

Chornesky EA, Bartuska AM, Aplet GH, et al (2005) Science Priorities for Reducing the Threat of Invasive Species to Sustainable Forestry. BioScience 55:335-348. doi: 10.1641/0006-3568(2005)055[0335:SPFRTT]2.0.CO;2

Cooke DEL, Drenth A, Duncan JM, et al (2000) A Molecular Phylogeny of Phytophthora and Related Oomycetes. Fungal Genet Biol 30:17-32. doi:

10.1006/fgbi.2000.1202 
Crous PW, Groenewald JZ, Slippers B, Wingfield MJ (2016) Global food and fibre security threatened by current inefficiencies in fungal identification. Phil Trans R Soc B 371:20160024. doi: 10.1098/rstb.2016.0024

Crowl TA, Crist TO, Parmenter RR, et al (2008) The spread of invasive species and infectious disease as drivers of ecosystem change. Front Ecol Environ 6:238-246. doi: $10.1890 / 070151$

Dale A, Feau N, Ponchart J, et al (2017) Urban activities influence on Phytophthora species diversity in British Columbia, Canada. In: Frankel, Susan J.; Harrell, Katharine M., tech. coords. Proceedings of the Sudden Oak Death Sixth Science Symposium. Gen. Tech. Rep. GTR-PSW-255. Albany, CA: U.S. Department of Agriculture, Forest Service, Pacific Southwest Research Station, pp 31-32

Davison EM, Drenth A, Kumar S, et al (2006) Pathogens associated with nursery plants imported into Western Australia. Australas Plant Pathol 35:473-475. doi: 10.1071/AP06043

Denman S, Kirk SA, Brasier CM, et al (2005) Phytophthora ramorum on Quercus ilex in the United Kingdom. Plant Dis 89:1241-1241. doi: 10.1094/PD-89-1241A

Denman S, Kirk SA, Moralejo E, Webber JF (2009) Phytophthora ramorum and Phytophthora kernoviae on naturally infected asymptomatic foliage. EPPO Bull 39:105-111. doi: 10.1111/j.1365-2338.2009.02243.x

Dick MA, Dobbie K, Cooke DEL, Brasier CM (2006) Phytophthora captiosa sp. nov. and P. fallax sp. nov. causing crown dieback of Eucalyptus in New Zealand. Mycol Res 110:393-404. doi: 10.1016/j.mycres.2006.01.008

Dickinson JL, Zuckerberg B, Bonter DN (2010) Citizen Science as an Ecological Research Tool: Challenges and Benefits. Annu Rev Ecol Evol Syst 41:149-172. doi: 10.1146/annurev-ecolsys-102209-144636

Donovan GH, Butry DT, Michael YL, et al (2013) The Relationship Between Trees and Human Health. Am J Prev Med 44:139-145. doi: 10.1016/j.amepre.2012.09.066

Durán A, Gryzenhout M, Slippers B, et al (2008) Phytophthora pinifolia sp. nov. associated with a serious needle disease of Pinus radiata in Chile. Plant Pathol 57:715-727. doi: 10.1111/j.1365-3059.2008.01893.x

Elliott M, Rollins L, Chastagner G (2017) Monitoring streams and stormwater ponds for early detection of oomycete plant pathogens in western Washington, a citizen science project. In: Frankel, Susan J.; Harrell, Katharine M., tech. coords. Proceedings of the Sudden Oak Death Sixth Science Symposium. Gen. Tech. Rep. GTR-PSW-255. Albany, CA: U.S. Department of Agriculture, Forest Service, Pacific Southwest Research Station, pp 70-71 
Érsek T, English JT, Schoelz JE (1995) Creation of Species Hybrids of Phytophthora with Modified Host Rangers by Zoospore Fusion. Phytopathology 85:1343-1347.

Faulkner KT, Robertson MP, Rouget M, Wilson JRU (2015) Understanding and managing the introduction pathways of alien taxa: South Africa as a case study. Biol Invasions 1-15. doi: 10.1007/s10530-015-0990-4

Gaertner M, Breeyen AD, Hui C, Richardson DM (2009) Impacts of alien plant invasions on species richness in Mediterranean-type ecosystems: a meta-analysis. Prog Phys Geogr 33:319-338. doi: 10.1177/0309133309341607

Gallo T, Waitt D (2011) Creating a Successful Citizen Science Model to Detect and Report Invasive Species. BioScience 61:459-465. doi: 10.1525/bio.2011.61.6.8

Garbelotto M, Barbosa D, Mehl H, Rizzo DM (2013) First Report of the NA2 Lineage of Phytophthora ramorum from an Ornamental Rhododendron in the Interior of California. Plant Dis 98:849-849. doi: 10.1094/PDIS-10-13-1043-PDN

Garbelotto M, Svihra P, Rizzo DM (2001) New pests and diseases: Sudden oak death syndrome fells 3 oak species. Calif Agric 55:9-19. doi: 10.3733/ca.v055n01p9

Ghimire SR, Richardson PA, Kong P, et al (2011) Distribution and Diversity of Phytophthora species in Nursery Irrigation Reservoir Adopting Water Recycling System During Winter Months. J Phytopathol 159:713-719. doi: 10.1111/j.14390434.2011.01831.x

Grünwald NJ, Garbelotto M, Goss EM, et al (2012a) Emergence of the sudden oak death pathogen Phytophthora ramorum. Trends Microbiol 20:131-138. doi: 10.1016/j.tim.2011.12.006

Grünwald NJ, Werres S, Goss EM, et al (2012b) Phytophthora obscura sp. nov., a new species of the novel Phytophthora subclade 8d: Phytophthora obscura as a new species. Plant Pathol 61:610-622. doi: 10.1111/j.1365-3059.2011.02538.x

Hansen EM (2008) Alien Forest Pathoges: Phytophthora species are changing world forests. Boreal Environ Res 13:33-41.

Hansen EM (2015) Phytophthora Species Emerging as Pathogens of Forest Trees. Curr For Rep 1-9. doi: 10.1007/s40725-015-0007-7

Hansen EM, Parke JL, Sutton W (2005) Susceptibility of Oregon Forest Trees and Shrubs to Phytophthora ramorum: A Comparison of Artificial Inoculation and Natural Infection. Plant Dis 89:63-70. doi: 10.1094/PD-89-0063

Hansen EM, Reeser P, Sutton W, Brasier CM (2015) Redesignation of Phytophthora taxon Pgchlamydo as Phytophthora chlamydospora sp. nov. North Am Fungi 10:1-14. 
Hansen EM, Reeser PW, Sutton W (2012) Phytophthora Beyond Agriculture. Annu Rev Phytopathol 50:359-378. doi: 10.1146/annurev-phyto-081211-172946

Hansen EM, Wilcox WF, Reeser PW, Sutton W (2009) Phytophthora rosacearum and P. sansomeana, new species segregated from the Phytophthora megasperma “complex." Mycologia 101:129-135. doi: 10.3852/07-203

Hardy GESJ, Vear K, O'Gara E, Williams NM (2007) Detection, diagnosis and mapping of native areas infested by Phytophthora species in Western Australia. Braz Phytopathol 32:S45-S46.

Henricot B, Pérez Sierra A, Jung T (2014) Phytophthora pachypleura sp. nov., a new species causing root rot of Aucuba japonica and other ornamentals in the United Kingdom. Plant Pathol 63:1095-1109. doi: 10.1111/ppa.12194

Herrero ML, Toppe B, Klemsdal SS, Stensvand A (2006) First Report of Phytophthora ramorum in Ornamental Plants in Norway. Plant Dis 90:1458-1458. doi: 10.1094/PD-90-1458B

Hooper DU, Adair EC, Cardinale BJ, et al (2012) A global synthesis reveals biodiversity loss as a major driver of ecosystem change. Nature 486:105-108. doi: 10.1038 /nature11118

Hulbert JM (2016) Citizen science tools available for ecological research in South Africa. South Afr J Sci. doi: 10.17159/sajs.2016/a0152

Hulme PE (2006) Beyond control: wider implications for the management of biological invasions. J Appl Ecol 43:835-847. doi: 10.1111/j.1365-2664.2006.01227.x

Hulme PE (2009) Trade, transport and trouble: managing invasive species pathways in an era of globalization. J Appl Ecol 46:10-18. doi: 10.1111/j.1365-

2664.2008.01600.x

Hulvey J, Gobena D, Finley L, Lamour K (2010) Co-occurrence and genotypic distribution of Phytophthora species recovered from watersheds and plant nurseries of eastern Tennessee. Mycologia 102:1127-1133. doi: 10.3852/09-221

Jung T, Chang TT, Bakonyi J, et al (2017) Diversity of Phytophthora species in natural ecosystems of Taiwan and association with disease symptoms. Plant Pathol 66:194-211. doi: 10.1111/ppa.12564

Jung T, Jung MH, Scanu B, et al (2016a) Six new Phytophthora species from ITS Clade 7 a including two sexually functional heterothallic hybrid species detected in natural ecosystems in Taiwan. Persoonia 38:100-135. doi: 10.3767/003158517X693615 
Jung T, Orlikowski L, Henricot B, et al (2016b) Widespread Phytophthora infestations in European nurseries put forest, semi-natural and horticultural ecosystems at high risk of Phytophthora diseases. For Pathol 46:134-163. doi: 10.1111/efp.12239

Leung B, Lodge DM, Finnoff D, et al (2002) An ounce of prevention or a pound of cure: bioeconomic risk analysis of invasive species. Proc R Soc Lond B Biol Sci 269:2407-2413. doi: 10.1098/rspb.2002.2179

Liebhold AM, Brockerhoff EG, Garrett LJ, et al (2012) Live plant imports: the major pathway for forest insect and pathogen invasions of the US. Front Ecol Environ 10:135-143. doi: 10.1890/110198

Lombaert E, Guillemaud T, Cornuet J-M, et al (2010) Bridgehead Effect in the Worldwide Invasion of the Biocontrol Harlequin Ladybird. PLoS ONE 5:e9743. doi: 10.1371/journal.pone.0009743

Lowe S, Browne M, Boudjelas S, De Poorter M (2000) 100 of the world's worst invasive alien species: a selection from the global invasive species database.

Mace GM, Norris K, Fitter AH (2012) Biodiversity and ecosystem services: a multilayered relationship. Trends Ecol Evol 27:19-26. doi:

10.1016/j.tree.2011.08.006

Maseko B, Burgess TI, Coutinho TA, Wingfield MJ (2007) Two new Phytophthora species from South African Eucalyptus plantations. Mycol Res 111:1321-1338. doi: 10.1016/j.mycres.2007.08.011

McCullough DG, Work TT, Cavey JF, et al (2006) Interceptions of Nonindigenous Plant Pests at US Ports of Entry and Border Crossings Over a 17-year Period. Biol Invasions 8:611. doi: 10.1007/s10530-005-1798-4

McTaggart AR, Nest MA van der, Steenkamp ET, et al (2016) Fungal Genomics Challenges the Dogma of Name-Based Biosecurity. PLOS Pathog 12:e1005475. doi: 10.1371/journal.ppat.1005475

Meentemeyer RK, Dorning MA, Vogler JB, et al (2015) Citizen science helps predict risk of emerging infectious disease. Front Ecol Environ 13:189-194. doi: $10.1890 / 140299$

Migliorini D, Ghelardini L, Tondini E, et al (2015) The potential of symptomless potted plants for carrying invasive soilborne plant pathogens. Divers Distrib 21:12181229. doi: $10.1111 /$ ddi. 12347

Moralejo E, Pérez-Sierra AM, Álvarez LA, et al (2009) Multiple alien Phytophthora taxa discovered on diseased ornamental plants in Spain. Plant Pathol 58:100-110. doi: 10.1111/j.1365-3059.2008.01930.x 
O'Hanlon R, Choiseul J, Corrigan M, et al (2016) Diversity and detections of Phytophthora species from trade and non-trade environments in Ireland. EPPO Bull n/a-n/a. doi: 10.1111/epp.12331

Pejchar L, Mooney HA (2009) Invasive species, ecosystem services and human wellbeing. Trends Ecol Evol 24:497-504. doi: 10.1016/j.tree.2009.03.016

Pyšek P, Richardson DM (2010) Invasive Species, Environmental Change and Management, and Health. Annu Rev Environ Resour 35:25-55. doi: 10.1146/annurev-environ-033009-095548

Rizzo DM, Garbelotto M (2003) Sudden oak death: endangering California and Oregon forest ecosystems. Front Ecol Environ 1:197-204.

Rizzo DM, Garbelotto M, Davidson JM, et al (2002) Phytophthora ramorum as the Cause of Extensive Mortality of Quercus spp. and Lithocarpus densiflorus in California. Plant Dis 86:205-214. doi: 10.1094/PDIS.2002.86.3.205

Sansford CE, Inman AJ, Baker R, et al (2009) Report on the risk of entry, establishment, spread and socio-economic loss and environmental impact and the appropriate level of management for Phytophthora ramorum for the EU. EU Sixth Framework Project RAPRA

Scanu B, Hunter GC, Linaldeddu BT, et al (2014) A taxonomic re-evaluation reveals that Phytophthora cinnamomi and P. cinnamomi var. parvispora are separate species. For Pathol 44:1-20. doi: 10.1111/efp.12064

Scott P, Burgess T, Hardy G (2013) Globalization and Phytophthora. In: Lamour K (ed) Phytophthora: a global perspective. CAB International, Cambridge, MA, pp 226232

van Wilgen BW, Forsyth GG, Le Maitre DC, et al (2012) An assessment of the effectiveness of a large, national-scale invasive alien plant control strategy in South Africa. Biol Conserv 148:28-38. doi: 10.1016/j.biocon.2011.12.035

Vitousek PM, D’Antonio CM, Loope LL, Westbrooks R (1996) Biological Invasions as global environmental change. J Am Sci 84:468-478.

Weir BS, Paderes EP, Anand N, et al (2015) A taxonomic revision of Phytophthora Clade 5 including two new species, Phytophthora agathidicida and P. cocois. Phytotaxa 205:21. doi: 10.11646/phytotaxa.205.1.2

WEO (2016) IMF World Economic Outlook April 2016-WEO Groups and Aggregates Information. https://www.imf.org/external/pubs/ft/weo/2016/02/weodata/groups.htm\#mae. Accessed 7 Nov 2016 
Werres S, Marwitz R, Man In't veld WA, et al (2001) Phytophthora ramorum sp. nov., a new pathogen on Rhododendron and Viburnum. Mycol Res 105:1155-1165. doi: $10.1016 / \mathrm{S} 0953-7562(08) 61986-3$

Werres S, Wagner S, Brand T, et al (2007) Survival of Phytophthora ramorum in Recirculating Irrigation Water and Subsequent Infection of Rhododendron and Viburnum. Plant Dis 91:1034-1044. doi: 10.1094/PDIS-91-8-1034

Wilson EO (1989) Threats to Biodiversity. Sci Am 261:108-112.

Wingfield MJ, Brockerhoff EG, Wingfield BD, Slippers B (2015) Planted forest health: The need for a global strategy. Science 349:832-836. doi: $10.1126 /$ science.aac6674

Yang X, Balci Y, Brazee NJ, et al (2016) A unique species in Phytophthora clade 10, Phytophthora intercalaris sp. nov., recovered from stream and irrigation water in the eastern USA. Int J Syst Evol Microbiol 66:845-855. doi:

10.1099/ijsem.0.000800 
Table 1 Phytophthora species with type specimens from urban environments.

\begin{tabular}{|c|c|c|c|c|c|c|c|c|}
\hline Species & Location & $\begin{array}{c}\text { Also in } \\
\text { natural } \\
\text { environment }\end{array}$ & $\begin{array}{l}\text { Holotype } \\
\text { from } \\
\text { nursery } \\
\end{array}$ & $\begin{array}{c}\text { Ornamental } \\
\text { host }\end{array}$ & $\begin{array}{c}\text { Ornamental } \\
\text { nurseries } \\
\text { elsewhere }\end{array}$ & Country & $\begin{array}{l}\text { IMF WEO } \\
\text { Economy }\end{array}$ & Publication \\
\hline P. pachypleura & Botanical garden & $\mathrm{N}$ & $\mathrm{N}$ & $\mathrm{Y}$ & $\mathrm{N}$ & UK & MA & Henricot et al. 2016 \\
\hline P. chlamydospora & Urban street & Y & $\mathrm{N}$ & $\mathrm{Y}$ & $\mathrm{N}$ & UK & MA & Hansen et al. 2015 \\
\hline P. mississippiae & Nursery & $\mathrm{N}$ & $\mathrm{Y}$ & NA & $\mathrm{N}$ & USA & MA & Yang et al. 2013 \\
\hline$P$. parvispora & Public space & Y & $\mathrm{N}$ & $\mathrm{N}$ & $\mathrm{N}$ & Italy & MA & Scanu et al. 2013 \\
\hline P. obscura & Public space & $\mathrm{N}$ & $\mathrm{N}$ & $\mathrm{N}$ & $\mathrm{Y}$ & Germany & MA & Grünwald et al. 2012 \\
\hline P. foliorum & Nursery & $\mathrm{N}$ & $\mathrm{Y}$ & $\mathrm{Y}$ & $\mathrm{Y}$ & USA & MA & Donahoo et al. 2006 \\
\hline P. ramorum & Nursery & $\mathrm{Y}$ & $\mathrm{Y}$ & $\mathrm{Y}$ & $\mathrm{Y}$ & Germany & MA & Werres et al. 2001 \\
\hline P. macilentosa & Nursery & $\mathrm{N}$ & $\mathrm{Y}$ & NA & $\mathrm{N}$ & USA & MA & Yang et al. 2014 \\
\hline P. hydrogena & Nursery & $\mathrm{N}$ & $\mathrm{Y}$ & NA & $\mathrm{N}$ & USA & MA & Yang et al. 2014 \\
\hline P. virginiana & Nursery & $\mathrm{N}$ & $\mathrm{Y}$ & NA & $\mathrm{N}$ & USA & MA & Yang and Hong 2013 \\
\hline P. irrigata & Nursery & $\mathrm{Y}$ & $\mathrm{Y}$ & NA & $\mathrm{Y}$ & USA & MA & Hong et al. 2008 \\
\hline P. polonica & Public space & Y & $\mathrm{N}$ & $\mathrm{N}$ & $\mathrm{N}$ & Poland & $\mathrm{E} \& \mathrm{D}$ & Belbahri et al. 2006 \\
\hline P. hydropathica & Nursery & $\mathrm{N}$ & $\mathrm{Y}$ & NA & $\mathrm{Y}$ & USA & MA & Hong et al. 2010 \\
\hline P. stricta & Nursery & $\mathrm{Y}$ & $\mathrm{Y}$ & NA & $\mathrm{N}$ & USA & MA & Yang et al. 2014 \\
\hline P. hedraiandra & Nursery $^{\mathrm{a}}$ & $\mathrm{N}$ & $\mathrm{Y}$ & $\mathrm{Y}$ & $\mathrm{Y}$ & Netherlands & $\mathrm{A}$ & deCock and Lévesque 2004 \\
\hline P. occultans & Nursery $^{\mathrm{b}}$ & $\mathrm{N}$ & $\mathrm{Y}$ & $\mathrm{Y}$ & $\mathrm{Y}$ & Netherlands & A & Man in 't Veld et al. 2014 \\
\hline P. terminalis & Nursery $^{b}$ & $\mathrm{~N}$ & $\mathrm{Y}$ & $\mathrm{Y}$ & $\mathrm{N}$ & Netherlands & A & Man in 't Veld et al. 2014 \\
\hline P. lacustris & Public space $^{c}$ & $\mathrm{Y}$ & $\mathrm{N}$ & $\mathrm{Y}$ & $\mathrm{Y}$ & UK & MA & Nechwatal et al. 2013 \\
\hline
\end{tabular}

$\mathrm{Y}=$ yes, $\mathrm{N}=$ no, $\mathrm{NA}=$ not available

${ }^{1}$ IMF World Economy Outlook, MA = Major Advanced, A = Advanced, E\&D = Emerging and Developing (WEO 2016).

${ }^{a}$ Assumed to be isolated from a nursery because of host and source of cultures (De Cock and Lévesque 2004).

${ }^{\mathrm{b}}$ Assumed to be isolated from a nursery because hosts were ornamental and some additional specimens were collected from horticultural centers

(Man in 't Veld et al. 2015).

${ }^{\mathrm{c}}$ Interpreted as public space because holotype was isolated from ornamental plant near a stream (Nechwatal et al. 2013). 
Table 2 Host and demographic data from first report publications for Phytophthora ramorum.

\begin{tabular}{|c|c|c|c|c|c|}
\hline Host & Country & $\begin{array}{l}\text { IMF WEO } \\
\text { Economy }^{1}\end{array}$ & Environment & Year & Source (doi if available) \\
\hline Rhododendron sp. & $\begin{array}{l}\text { Germany and } \\
\text { the Netherlands }\end{array}$ & A & Urban & 1997 & Werres \& Marwitz 1997 \\
\hline Viburnum sp. & $\begin{array}{l}\text { Germany and } \\
\text { the Netherlands }\end{array}$ & A & Urban & 2001 & $10.1016 / \mathrm{S} 0953-7562(08) 61986-3$ \\
\hline Pseudotsuga menziesii & USA & MA & Natural & 2002 & 10.1094/PDIS.2002.86.11.1274B \\
\hline Notholithocarpus densiflorus & USA & MA & Natural & 2002 & 10.1094/PDIS.2002.86.4.441C \\
\hline Rhododendron macrophyllum & USA & MA & Natural & 2002 & 10.1094/PDIS.2002.86.4.441C \\
\hline Vaccinium ovatum & USA & MA & Natural & 2002 & 10.1094/PDIS.2002.86.4.441C \\
\hline Viburnum tinus & United Kingdom & MA & Urban & 2002 & http://www.ndrs.org.uk/article.php?id=006013 \\
\hline Sequoia sempervirens & USA & MA & Natural & 2002 & 10.1094/PDIS.2002.86.11.1274A \\
\hline Rhodedendron spp. & Spain & A & Urban & 2002 & 10.1094/PDIS.2002.86.9.1052A \\
\hline Rhodedendron catawbiense & Poland & $E \& D$ & Urban & 2002 & Orlikowski \& Szkuta 2002 \\
\hline Viburnum bodnantense & Belgium & A & Urban & 2003 & 10.1094/PDIS.2003.87.2.203C \\
\hline Trientalis latifolia & USA & MA & Natural & 2003 & $\overline{10.1094 / \text { PDIS.2003.87.5.599B }}$ \\
\hline Pieris formosa var. forrestii & United Kingdom & MA & Urban & 2003 & $\overline{10.1111 / \mathrm{j} .1365-3059.2003 .00894 . \mathrm{x}}$ \\
\hline Quercus chrysolepis & USA & MA & Natural & 2003 & 10.1094/PDIS.2003.87.3.315C \\
\hline Camellia japonica & Spain & A & Urban & 2003 & 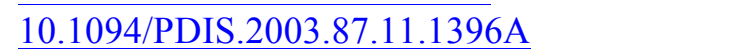 \\
\hline Syringa vulgaris & United Kingdom & MA & Urban & 2004 & $10.1111 / \mathrm{j} .1365-3059.2004 .01033 . \mathrm{x}$ \\
\hline Camellia spp. & United Kingdom & MA & Urban & 2004 & $\overline{10.1111 / \mathrm{j} .1365-3059.2004 .01028 . \mathrm{x}}$ \\
\hline Quercus falcata & United Kingdom & MA & $\mathrm{NA}^{\mathrm{a}}$ & 2004 & $10.1111 / \mathrm{j} .1365-3059.2004 .01079 . \mathrm{x}$ \\
\hline Hamamelis virginiana & United Kingdom & MA & Urban & 2004 & $10.1111 / \mathrm{j} .1365-3059.2004 .01034 . \mathrm{x}$ \\
\hline Rosa gymnocarpa & USA & MA & Natural & 2004 & 10.1094/PDIS.2004.88.4.430 \\
\hline Taxus baccata & United Kingdom & MA & Urban & 2004 & $10.1111 / \mathrm{j} .1365-3059.2004 .01022 . \mathrm{x}$ \\
\hline Camellia japonica & USA & MA & Urban & 2004 & 10.1094/PDIS.2004.88.1.87A \\
\hline Camellia sasanqua & USA & MA & Urban & 2004 & 10.1094/PDIS.2004.88.1.87A \\
\hline P. floribunda $\times$ japonica & USA & MA & Urban & 2004 & 10.1094/PDIS.2004.88.1.87A \\
\hline Pieris japonica & USA & MA & Urban & 2004 & 10.1094/PDIS.2004.88.1.87A \\
\hline Pieris japonica $\times$ formosa & USA & MA & Urban & 2004 & 10.1094/PDIS.2004.88.1.87A \\
\hline Rhododendron spp. & USA & MA & Urban & 2004 & $10.1094 /$ PDIS.2004.88.1.87A \\
\hline
\end{tabular}




\begin{tabular}{|c|c|c|c|c|c|}
\hline Viburnum bodnantense & USA & MA & Urban & 2004 & 10.1094/PDIS.2004.88.1.87A \\
\hline Viburnum plicatum var. & USA & MA & Urban & 2004 & 10.1094/PDIS.2004.88.1.87A \\
\hline tomentosum & & & & & \\
\hline $\begin{array}{l}\text { Rhodedendron } \\
\text { catawbiense 'Grandiflorum' }\end{array}$ & Slovenia & A & Urban & 2004 & $\underline{10.1111 / \mathrm{j} .1365-3059.2004 .01023 . \mathrm{x}}$ \\
\hline Viburnum farreri & Slovenia & A & Urban & 2004 & 10.1111/j.1365-3059.2004.01023.x \\
\hline Viburnum bodnantense & Slovenia & A & Urban & 2004 & 10.1111/j.1365-3059.2004.01023.x \\
\hline Castanea sativa & United Kingdom & MA & Urban & 2005 & 10.1111/j.1365-3059.2005.01222.x \\
\hline Quercus ilex & United Kingdom & MA & Multiple $^{\mathrm{b}}$ & 2005 & 10.1094/PD-89-1241A \\
\hline Maianthemum racemosum & USA & MA & Natural & 2005 & 10.1094/PD-89-0204C \\
\hline Rhododendron catawbiense & Norway & A & Urban & 2006 & 10.1094/PD-90-1458B \\
\hline Pittosporum undulatum & USA & MA & Urban & 2006 & $\overline{10.1071 / \mathrm{DN} 06009}$ \\
\hline Parrotia persica & United Kingdom & MA & Urban & 2006 & http://www.ndrs.org.uk/article.php?id=013011 \\
\hline Rhamnus purshiana & USA & MA & Natural & 2006 & 10.1094/PD-90-0246C \\
\hline Adiantum aleuticum & USA & MA & Natural & 2006 & 10.1094/PD-90-0379B \\
\hline Adiantum jordanii & USA & MA & Natural & 2006 & 10.1094/PD-90-0379B \\
\hline Griselinia littoralis & United Kingdom & MA & Urban $^{\mathrm{c}}$ & 2007 & $\overline{10.1111 / \mathrm{j} .1365-3059.2007 .01590 . \mathrm{x}}$ \\
\hline Magnolia loebneri & United Kingdom & MA & Urban $^{c}$ & 2007 & $10.1111 / \mathrm{j} .1365-3059.2007 .01590 . \mathrm{x}$ \\
\hline Magnolia stellata & United Kingdom & MA & Urban $^{c}$ & 2007 & 10.1111/j.1365-3059.2007.01590.x \\
\hline Camellia sp. & France & A & Urban & 2007 & 10.1094/PDIS-91-10-1359B \\
\hline Pieris japonica & France & A & Urban & 2007 & 10.1094/PDIS-91-10-1359B \\
\hline Rhodedendron spp. & France & $\mathrm{A}$ & Urban & 2007 & 10.1094/PDIS-91-10-1359B \\
\hline Viburnum bodnantense & France & A & Urban & 2007 & 10.1094/PDIS-91-10-1359B \\
\hline Viburnum tinus & France & $\mathrm{A}$ & Urban & 2007 & 10.1094/PDIS-91-10-1359B \\
\hline Rhodedendron spp. & Finland & A & Urban & 2007 & 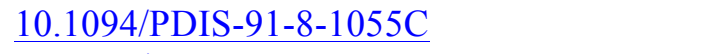 \\
\hline Acer circinatum & USA & MA & Natural & 2008 & 10.1094/PHP-2008-0118-02-BR \\
\hline Arctostaphylos columbiana & USA & MA & Natural & 2008 & 10.1094/PHP-2008-0118-02-BR \\
\hline Arctostaphylos manzanita & USA & MA & Natural & 2008 & $\underline{10.1094 / \mathrm{PHP}-2008-0118-02-\mathrm{BR}}$ \\
\hline Ceanothus thyrsiflorus & USA & MA & Natural & 2008 & 10.1094/PHP-2008-0118-02-BR \\
\hline $\begin{array}{l}\text { Corylus cornuta var. } \\
\text { californica }\end{array}$ & USA & MA & Natural & 2008 & $\underline{10.1094 / \mathrm{PHP}-2008-0118-02-\mathrm{BR}}$ \\
\hline Viburnum tinus & USA & MA & Urban & 2008 & 10.1094/PDIS-92-2-0314B \\
\hline Osmanthus heterophyllus & USA & MA & Urban & 2008 & 10.1094/PDIS-92-2-0314B \\
\hline Rhodedendron spp. & Serbia & E\&D & Urban & 2009 & 10.1111/j.1365-3059.2009.02033.x \\
\hline
\end{tabular}




\begin{tabular}{|c|c|c|c|c|c|}
\hline Abies magnifica & USA & MA & Agriculture & 2010 & 10.1094/PDIS-94-9-1170B \\
\hline Larix kaempferi & United Kingdom & MA & Agriculture & 2010 & $10.5197 / \mathrm{j} .2044-0588.2010 .022 .019$ \\
\hline Vaccinium myrtillus & Norway & A & Urban & 2011 & 10.1094/PDIS-10-10-0709 \\
\hline $\begin{array}{l}\text { Trachelospermum } \\
\text { jasminoides }\end{array}$ & USA & MA & Urban & 2011 & Osterbauer et al. 2011 \\
\hline Abies grandis & USA & MA & Agriculture & 2011 & 10.1094/PHP-2011-0401-01-BR \\
\hline Rhodedendron spp. & Greece & $\mathrm{A}$ & Urban & 2011 & 10.1094/PDIS-08-10-0607 \\
\hline Loropetalum chinense & USA & MA & Urban & 2012 & 10.1094/PDIS-01-12-0062-PDN \\
\hline Chamaecyparis lawsoniana & United Kingdom & MA & Agriculture & 2012 & $10.5197 / \mathrm{j} .2044-0588.2012 .025 .026$ \\
\hline Myristica fragrans & India & $\mathrm{E} \& \mathrm{D}$ & Agriculture & 2012 & Mathew \& Beena 2012 \\
\hline Cinnamomum camphora & USA & MA & Urban & 2013 & 10.1094/PDIS-01-13-0096-PDN \\
\hline Rhododendron spp. & USA & MA & Urban & 2014 & 10.1094/PDIS-10-13-1043-PDN \\
\hline Viburnum tinus & Italy & $\mathrm{A}$ & Urban & 2014 & 10.1094/PDIS-07-13-0767-PDN \\
\hline Gaultheria procumbens & USA & MA & Urban & 2014 & 10.1094/PHP-BR-13-0109 \\
\hline Notholithocarpus densiflorus & USA & MA & Natural & 2016 & 10.1094/PDIS-10-15-1169-PDN \\
\hline
\end{tabular}

${ }^{1}$ IMF World Economy Outlook, MA = Major Advanced, A = Advanced, E\&D = Emerging and Developing (WEO 2016).

${ }^{a}$ The isolates for this first report were recovered from a mature tree in south-east England in an unspecified environment.

'The isolates were recovered from infected trees at 'various woodland and garden sites in the UK' and 'recorded on saplings in nurseries'.

${ }^{\mathrm{c}}$ Assumed to be isolated from nurseries because the hosts are ornamental and the author affiliations include DEFRA PHSI. 
Figure 1 Phytophthora holotype distribution data for each country between 2001 and 2016.

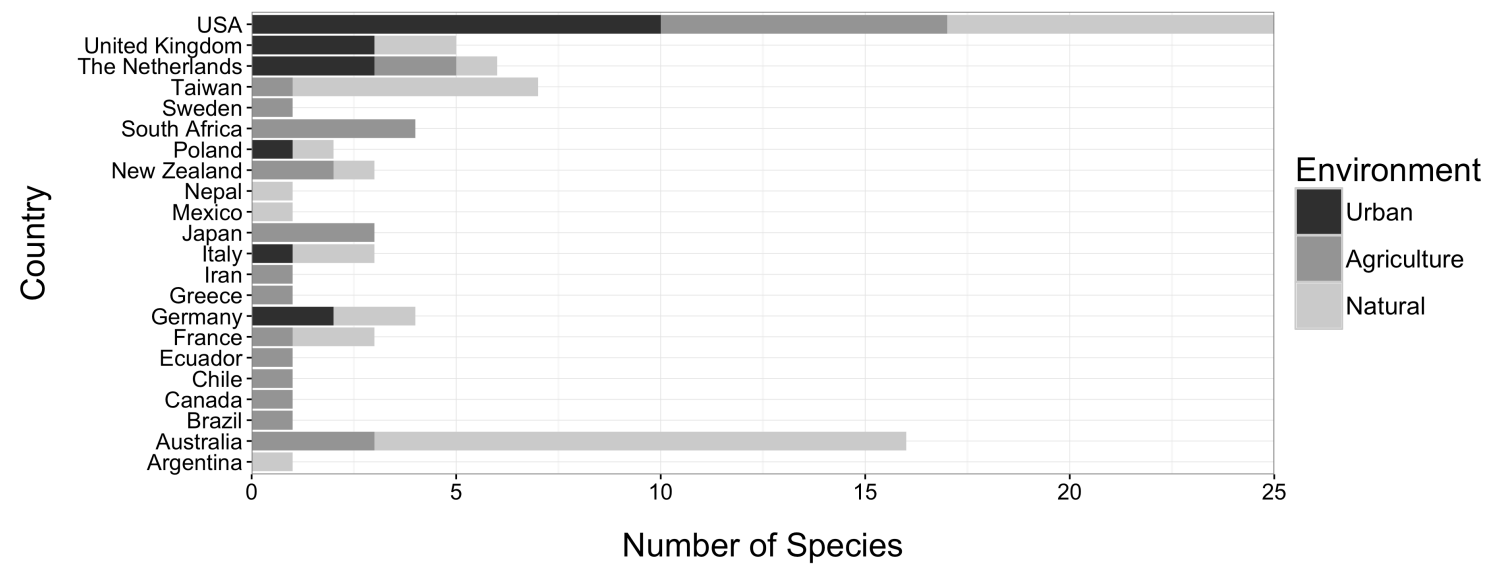

Figure 2 Phytophthora holotype distributions in urban environments for each country.

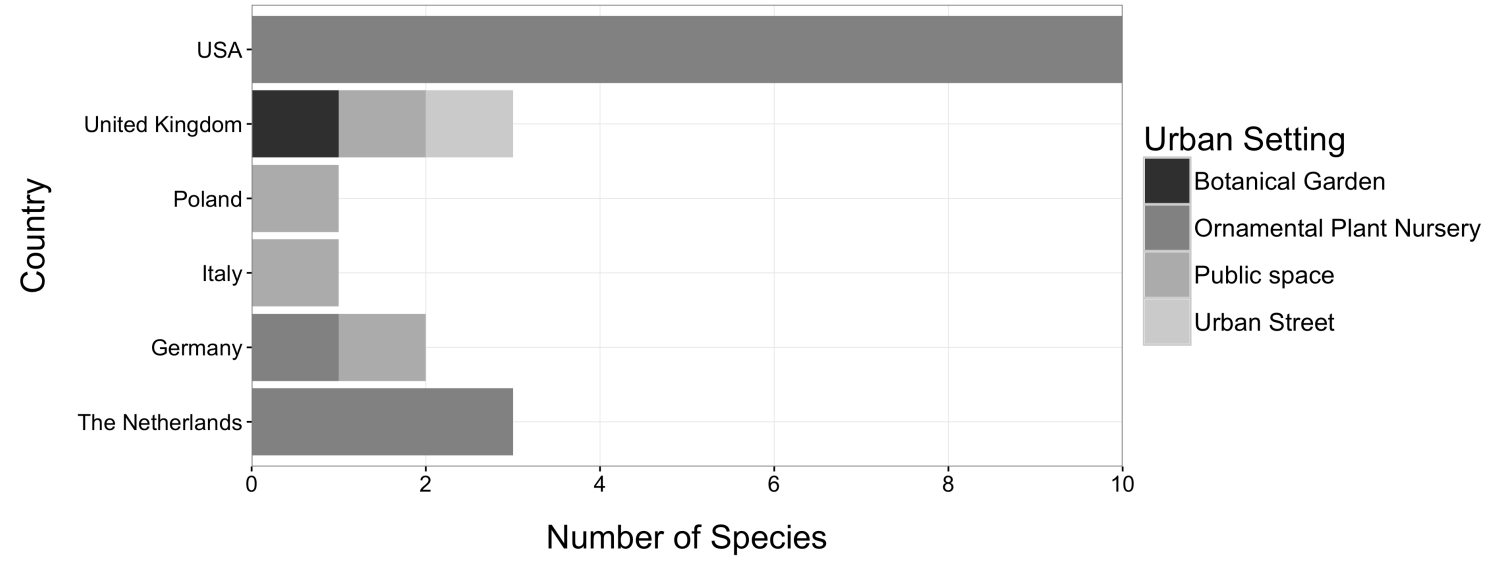

Figure 3 Phytophthora holotype distribution data within WEO economy classes between 2001 and 2016.

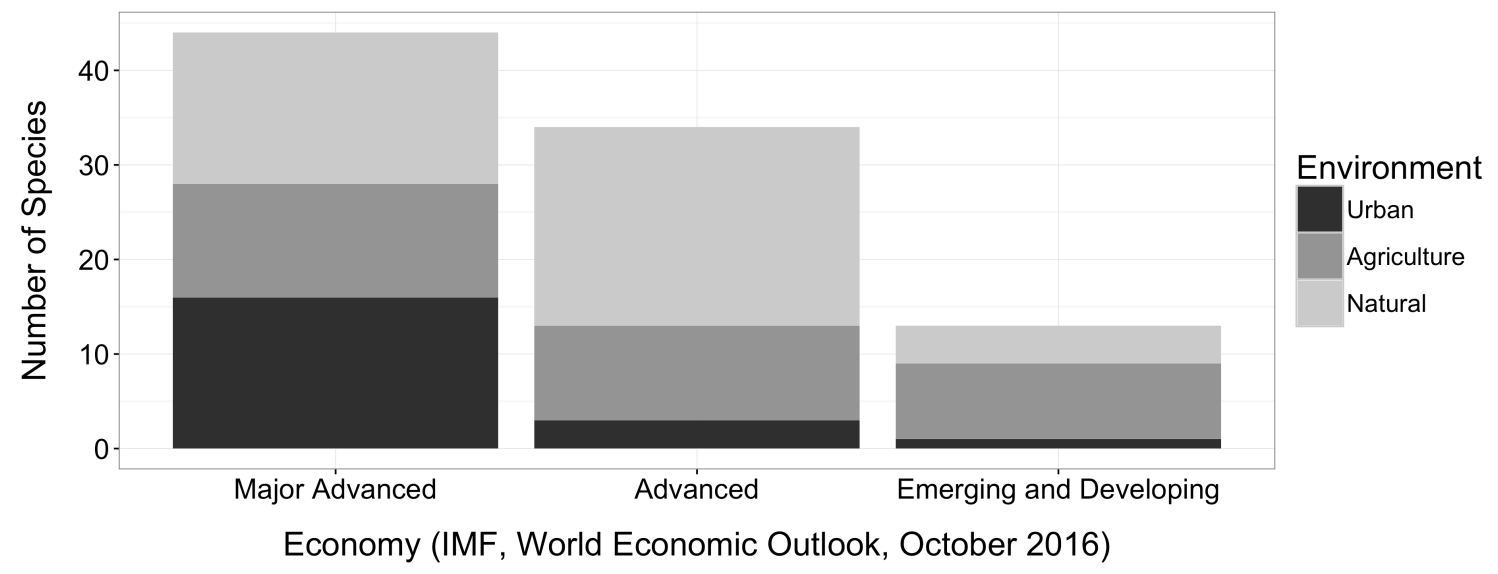

Figure 4 Phytophthora ramorum first report distributions by country. 


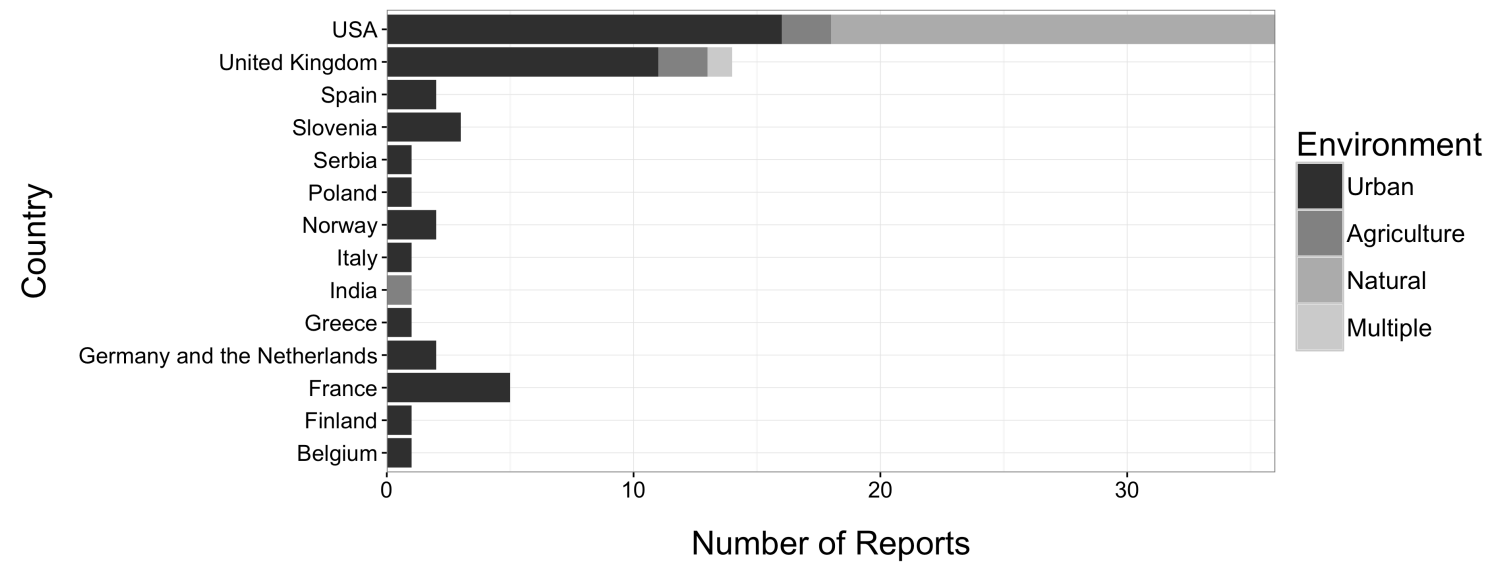

